\title{
MAGNESIORIEBECKITE AND PENNINITE FROM A SHEAR ZONE IN PUOLANKA, NE FINLAND
}

\author{
Kauko Laajoki and Pentti Ojanperä
}

\begin{abstract}
Laajoki, Kauko and Ojanperä, Pentti 1973: Magnesioriebeckite and penninite from a shear zone in Puolanka, NE Finland. Bull. Geol. Soc. Finland 45, 143-153.

Magnesioriebeckite and penninite are described from a shear zone. The chemical analyses, indexed powder diffraction data, unit cell dimensions, specific gravities and optical properties are given for these minerals. The zonality of magnesioriebeckite is described with the aid of semiquantitative electron probe microanalyses. The origin of magnesioriebeckite and penninite is discussed.
\end{abstract}

Kauko Laajoki and Pentti Ojanperä, Geological Survey of Finland, 02150 Otaniemi, Finland.

\section{Introduction}

During explorations carried out by the Geological Survey of Finland in the Puolanka area, NE Finland, in the summer of 1968 a shear zone between the Prekarelidic basement gneiss complex and the psammites of the Karelidic belt was intersected by a drill hole (No. 10, Fig. 1). In this shear zone a blue amphibole and a yellow mica-like mineral were detected which were identified as magnesioriebeckite and penninite, respectively. Their occurrence is restricted to the contacts of an albite-rich metadiabase. Associated minerals are carbonate, quartz, albite, biotite and talc.

Alkali amphiboles have been described in Finland from Kiihtelysvaara (riebeckite-arfvedsonite) (Eskola and Sahlstein 1930 a), Otanmäki (Hytönen and Heikkinen 1966), Siilinjärvi (richterite) (Puustinen 1972) and Savukoski (Paarma 1970). Magnesioriebeckite has not previously been described from Finland. The only analyzed Finnish »penninite» (actually chamosite) is that from Raajärvi (Nuutilainen 1968).

The purpose of this study is to give a mineralogical description of the magnesioriebeckite and penninite from Puolanka and to discuss their origin. Pentti Ojanperä performed the wet chemical analyses. Kauko Laajoki did the other mineralogical studies and wrote the manuscript.

\section{Petrography}

The shear zone under consideration is situated in the tectonic contact between the Prekarelidic basement gneiss complex and the Jatulian psammite formations of the Karelidic belt 

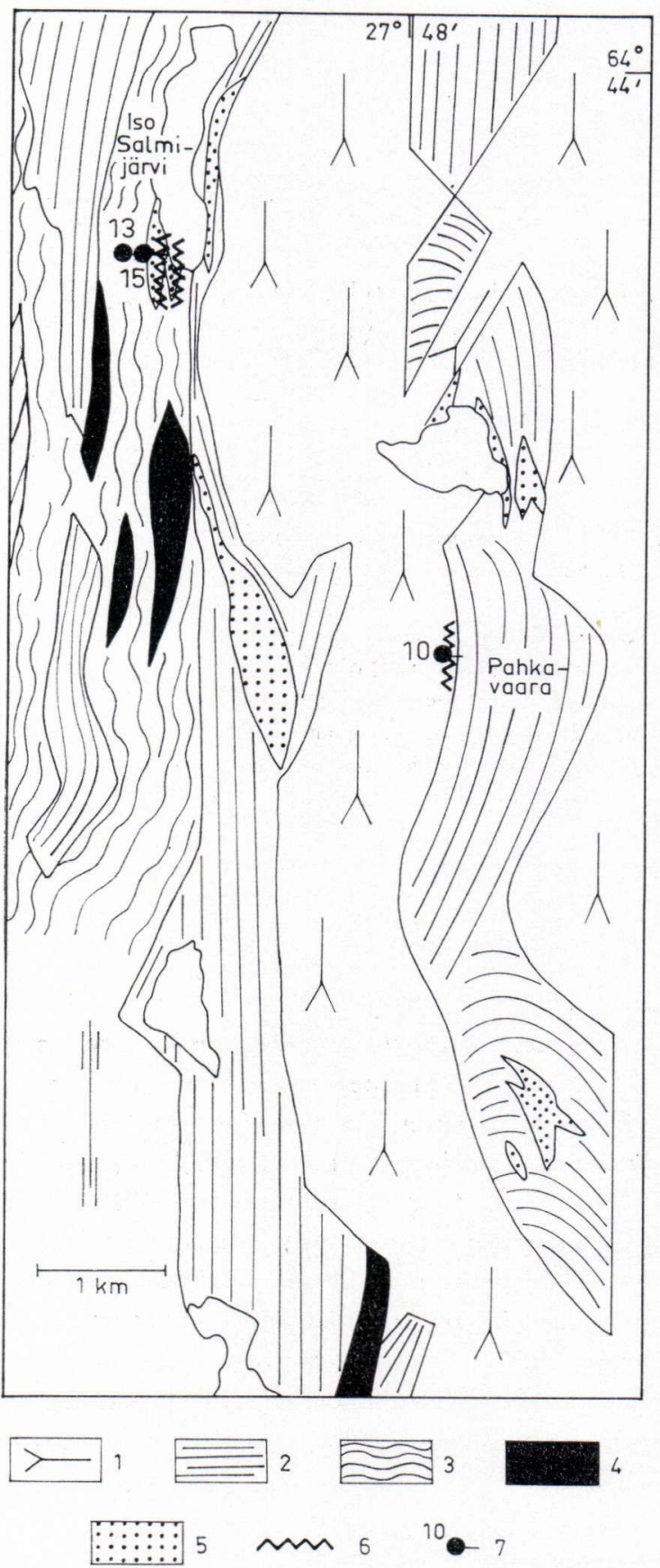

FIG. 1. The location of drill holes Nos 10, 13 and 15, Puolanka, NE Finland. The map is simplified after Laajoki (1973). 1) Prekarelidic basement gneiss complex. 2) Psammites of the Jatulian. 3) Phyllites and schists of the Dolomite-Phyllite Formation (Marine Jatulian). 4) Dolomite of the Dolomite-Phyllite Formation. 5) Metadiabase. 6) Shear zone. 7) Drill hole and number.

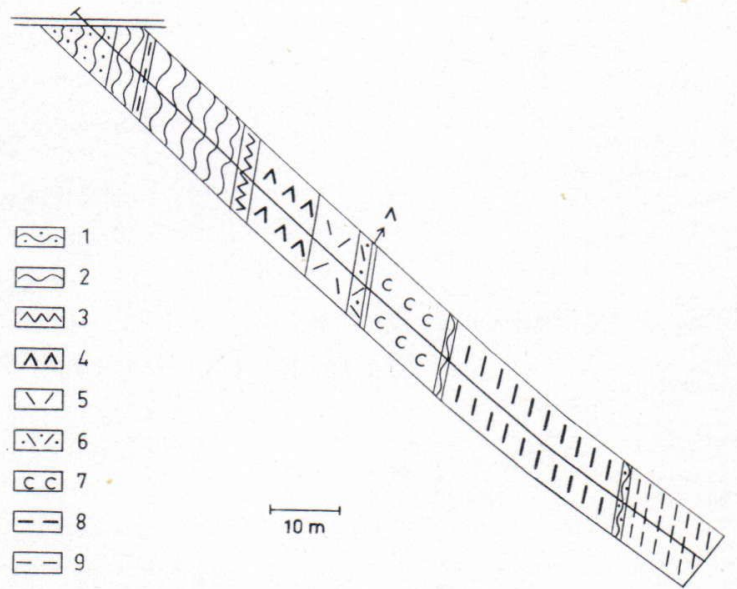

FIg. 2. The prophile of drill hole No. 10, Puolanka, NE Finland. 1) Mica gneiss. 2) Mica schist. 3) Biotite-chlorite schist. 4) Penninite- and magnesioriebeckite-bearing rock. 5) Albite metadiabase. 6) Albite-biotite metadiabase. 7) Carbonate rock. 8) Amphibolite. 9) Quartzite.

(Fig. 1). The basement complex consists mainly of granodioritic orthogneisses with microcline porphyroblasts. Drill hole No. 10 (Fig. 2) begins with mica gneisses and mica schists possibly belonging to the basement complex or to the Dolomite-Phyllite Formation. They are succeeded by a zone approximately $8 \mathrm{~m}$ thick of granoblastic penninite- and magnesioriebeckitebearing rocks. The mineralogy of this zone is very variable (Table 1 , Nos. $1-4$ ). The amount of penninite and magnesioriebeckite increases towards the contact of albite metadiabase and there are fragments of grey phyllite and albite metadiabase. Albite is often almost totally replaced by carbonate. Penninite- and magnesioriebeckite-bearing rock grades into subophitic albite metadiabase (Table 1, No. 5). Carbonate and a brownish yellow substance intimately associated with it occur as spots up to $5 \mathrm{~mm}$ in diameter and bctween the other minerals. According to electron probe examinations the brownish yellow substance contains $\mathrm{Ca}, \mathrm{Fe}, \mathrm{Al}$ and $\mathrm{Si}$ in varying amounts. Part of it was identified as iron-bearing carbonate. Albite metadiabase is succeeded by biotite metadiabase (Table 1 , 
TABLE 1

Mineral composition of the rocks of drill hole No. 10, Puolanka, NE Finland. Determined by the point counting method. Vol. \%.

\begin{tabular}{|c|c|c|c|c|c|c|c|c|c|}
\hline & 1 & 2 & 3 & 4 & 5 & 6 & 7 & 8 & 9 \\
\hline Quartz................ & - & 0.5 & - & 49.9 & - & 0.8 & - & 0.8 & 5.4 \\
\hline $\begin{array}{l}\text { Plagioclase } \ldots \ldots \ldots \ldots \ldots \ldots \\
(\text { An } \%)\end{array}$ & 18.8 & 0.3 & $\begin{array}{r}21.8 \\
(0-2)\end{array}$ & $\begin{array}{r}16.0 \\
(0)\end{array}$ & $\begin{array}{r}63.9 \\
(0-5)\end{array}$ & $\begin{array}{r}40.1 \\
(3-6)\end{array}$ & 34.3 & 1.0 & + \\
\hline Magnesioriebeckite ........ & 11.1 & 1.0 & 6.0 & 6.8 & - & - & 0.1 & - & 0.1 \\
\hline Biotite ............. & - & - & - & 0.8 & 2.1 & 41.3 & 5.7 & 3.0 & - \\
\hline Penninite $\ldots \ldots \ldots \ldots \ldots$ & 44.0 & 87.2 & 47,5 & 0.1 & - & - & - & 0.5 & - \\
\hline Talc $\ldots \ldots \ldots \ldots \ldots \ldots \ldots$ & 4.6 & 2.5 & 6.1 & 一 & - & - & - & 0.2 & 1.4 \\
\hline Carbonate $\ldots \ldots \ldots \ldots \ldots$ & 18.6 & 8.1 & 16.7 & 26.3 & 14.3 & $\left.10.9^{\mathrm{c}}\right)$ & $\left.59.8^{\mathrm{c}}\right)$ & $\left.94.1^{\mathrm{c}}\right)$ & 92.6 \\
\hline Apatite $\ldots \ldots \ldots \ldots \ldots \ldots$ & 0.8 & - & 0.3 & + & - & + & - & - & - \\
\hline Opaques $\ldots \ldots \ldots \ldots \ldots$ & 2.0 & - & - & + & $\left.7.8^{d}\right)$ & $\left.6.9^{d}\right)$ & 0.1 & 0.3 & 0.1 \\
\hline \multirow{2}{*}{ Others $\ldots \ldots \ldots \ldots \ldots \ldots$} & - & $\left.0.3^{\mathrm{a}}\right)$ & $\left.1.6^{\mathrm{a}}\right)$ & - & $\left.12.0^{\mathrm{a}}\right)$ & 一 & 一 & - & $\left.0.4^{\mathrm{b}}\right)$ \\
\hline & 99.9 & 99.9 & 100.0 & 99.9 & 100.1 & 100.0 & 100.0 & 99.9 & 100.0 \\
\hline
\end{tabular}

a) brownish yellow substance, b) tourmaline $0.2 \%$ and microcline $0.2 \%$, c) contains brownish yellow substance, d) mainly magnetite.

1) Penninite- and magnesioriebeckite-bearing rock, depth $44.35 \mathrm{~m}$

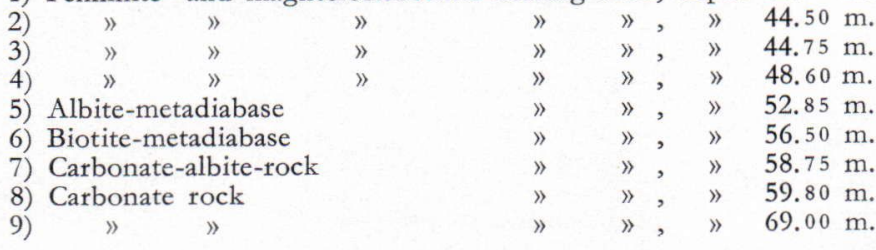

No. 6). According to three semiquantitative electron probe microanalyses, the biotite of metadiabases contains about $17 \% \mathrm{FeO}$ (total iron) and about $14 \% \mathrm{MgO}$. Biotite metadiabase grades into penninite and magnesioriebeckitebearing carbonate-albite-rock (Table 1, No. 7), which again grades into more or less pure carbonate rock (Table 1, Nos. 8-9). Carbonate, which according to the Alizar Red S-test is calcite, replaces albite and occasionally also magnesioriebeckite. The rock contains abundantly dark grey phyllite fragments. Some thin magnesioriebeckite- and/or pennitite -bearing seams occur.

The host rock of the shear zones intersected by drill holes Nos 13 and 15 (Fig. 1) is metadiabase containing ca. $75 \%$ green hornblende, ca. $25 \%$ oligoclase $\left(\mathrm{An}_{28-36}\right)$ and magnetite and biotite as accessories. The rocks of these shear zones are mainly carbonate rocks and quartzites. Especially in carbonate rocks chlorite-(penninite) rich parts and talc seams up to $20 \mathrm{~cm}$ broad are frequent. Microcline balls and fragments ranging up to $2 \mathrm{~cm}$ in diameter are typical of these shear zones. The balls and fragments consist mainly of fine- and even-grained microcline and quartz grains. Sometimes microcline occurs as phenocrysts in a fine-grained groundmass. Although these shear zones are very similar to that of drill hole No. 10 no magnesioriebeckite was found.

\section{Magnesioriebeckite}

Magnesioriebeckite occurs as euhedral needles ranging up to $2 \mathrm{~mm}$ in length. The main part of the amphibole is light blue in colour. Occasionally also dark blue crystals are encountered. These varieties are called magnesioriebeckite- 1 and magnesioriebeckite-2, respectively. For chemical analysis magnesioriebeckite-1 was separated 
TABLE 2

Chemical composition and physical properties of the magnesioriebeckite-1 from drill hole No. 10. Puolanka, NE Finland. Chemical analysis by Pentti Ojanperä. Optical data are for Na-light.

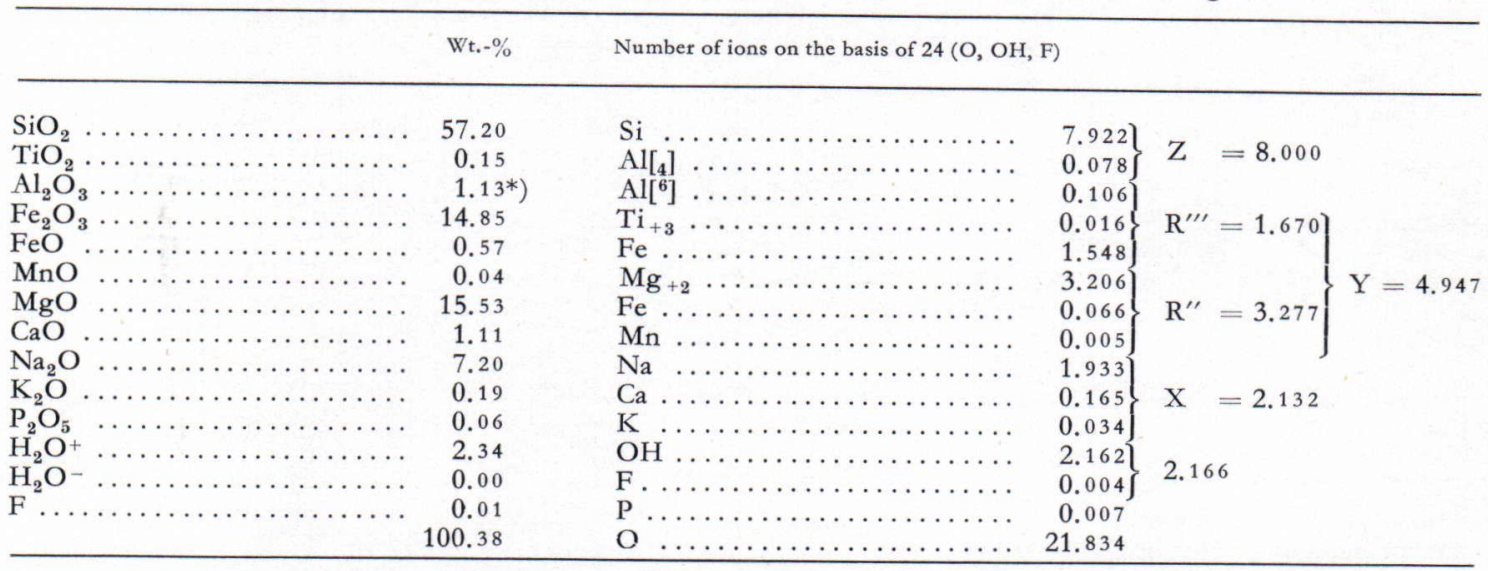

$\left(\mathrm{Na}_{1.93} \mathrm{~K}_{03} \mathrm{Ca} \cdot{ }_{16}\right)_{2.12}\left(\mathrm{Mg}_{3.21} \mathrm{Fe}_{.07}^{+2} \mathrm{Mn} .{ }_{00}\right)_{3.28}\left(\mathrm{Fe}_{1.55}^{+3} \mathrm{Al}_{.11} \mathrm{Ti}_{02}\right)_{1.68}\left(\mathrm{Si}_{7.92} \mathrm{Al} ._{08}\right)_{8.00} \mathrm{O}_{21.83}(\mathrm{OH}, \mathrm{F})_{2.16}$

*) Anal. A. Löfgren.

a)

$$
\begin{aligned}
& \alpha \quad=1.657 \pm 0.002 \\
& \gamma \quad=1.670 \pm 0.002 \\
& \mathrm{C} \wedge \alpha=9-13^{\circ} \\
& 2 V_{\alpha}=0-4^{\circ} \\
& \mathrm{D}_{\text {meas }}=3.11_{6} \\
& \mathrm{D}_{\text {calc }}=3.108
\end{aligned}
$$

b)

$1.659 \pm 0.002$

$1.674 \pm 0.002$

$3.12_{2}$ (Westphal balance)
Pleochroism

$\alpha=$ light blue

$\beta=$ light violet

$\gamma=$ yellowish

a) almost colourless

b) blue

from the core of drill hole No. 10, depth 44.35$44.90 \mathrm{~m}$ using Clerici's solution and a Franz isodynamic separator. The final purification was done by hand picking under a binocular microscope until no foreign grains were detected. Slight quantities were seen in some grains of a reddish brown pigment which was insoluble in hydrocloridic acid. Under a binocular microscope and in immersion liquids the colour of magnesioriebeckite-1 varied from almost colourless to blue.

The chemical analysis of magnesioriebeckite-1 is presented in Table 2. It is very close in composition to that of theoretical magnesioriebeckite (Table 4). As, however, the number of $\mathrm{R}^{\text {"' }}$ is less than 2.00 and the number of $\mathrm{X}$ more than
Orientation of indicatrix.

O.A.P. $\quad / /(010)$

$\mathrm{b}=\beta$

Unit cell dimensions $(C 2 / m)$

$a_{0}=9.700 \pm 0.010 \AA$

$b_{0}=17.944 \pm 0.018 \AA$

$c_{0}=5.273 \pm 0.005 \AA$

$\beta=103^{\circ} 32^{\prime}+05^{\prime}$

$\mathrm{V}=892.4 \AA^{3}$
2.00 the Puolanka amphibole has arfvedsonitic affinities ( $c f$. Borg 1967). On the basis of the refractive indices and the specific gravities given in Table 2 the darker magnesioriebeckite- 1 is slightly richer in iron than the lighter one. In thin section magnesioriebeckite-1 is slightly zoned with an almost colourless core and a pale blue margin. The margin has higher refractive indices than the core. In this respect magnesioriebeckite-1 resembles that of Bizan (Miyashiro and Iwasaki 1957). The interference colour is an anomalous blue. As in the case of many other alkali amphiboles, it also has incomplete extinction. The incomplete extinction of alkali amphiboles has been attributed to the inter. 
TABLE 3.

Indexed powder diffraction pattern of the Puolanka magnesioriebeckite-1 (space group $C 2 / \mathrm{m}$ ). Filtered copper radiation with $\mathrm{Si}$-standard. X-ray runs by Pekka Kallio.

\begin{tabular}{|c|c|c|c|c|}
\hline & bkl & $I$ & $d_{\text {meas }}$ & $d_{\text {ealc }}$ \\
\hline & & 7 & $9.36 *)$ & \\
\hline 020 & $\ldots \ldots \ldots$ & & & 8.97 \\
\hline 110 & $\ldots \ldots \ldots \ldots$ & $\begin{array}{r}100 \\
2\end{array}$ & $\begin{array}{l}8.35 *) \\
4.844\end{array}$ & 8.35 \\
\hline$\overline{1} 11$ & $\ldots \ldots \ldots \ldots$ & 3 & 4.836 & 4.838 \\
\hline 040 & $\ldots \ldots \ldots \ldots$ & 16 & 4.486 & 4.486 \\
\hline 220 & $\ldots \ldots \ldots \ldots$ & $\begin{array}{r}20 \\
1\end{array}$ & $\begin{array}{l}4.225 \\
3.439\end{array}$ & 4.174 \\
\hline 131 & $\ldots \ldots \ldots$ & 9 & 3.396 & 3.392 \\
\hline 240 & $\ldots \ldots \ldots$ & 18 & 3.246 & 3.250 \\
\hline 310 & $\ldots \ldots \ldots$ & +100 & 3.092 & 3.097 \\
\hline 221 & $\ldots \ldots \ldots$ & 5 & 2.954 & 2.952 \\
\hline 330 & $\ldots \ldots \ldots \ldots$ & 2 & 2.798 & 2.783 \\
\hline 151 & $\ldots \ldots \ldots$ & 12 & 2.692 & 2.706 \\
\hline 061 & $\ldots \ldots \ldots$ & 4 & 2.583 & 6.583 \\
\hline$\overline{2} 02$ & $\ldots \ldots \ldots$ & 5 & 2.525 & 2.512 \\
\hline$\overline{3} 51$ & $\ldots \ldots \ldots$ & 5 & 2.308 & 2.307 \\
\hline$\overline{1} 71$ & $\ldots \ldots \ldots$ & 4 & 2.284 & 2.283 \\
\hline$\overline{3} 12$ & $\ldots \ldots \ldots$ & 2 & 2.255 & 2.245 \\
\hline 261 & $\ldots \ldots \ldots$ & 5 & 2.164 & 2.161 \\
\hline 351 & $\ldots \ldots \ldots$ & 4 & 2.013 & 2.017 \\
\hline 242 & $\ldots \ldots \ldots$ & 9 & 1.873 & 1.871 \\
\hline 191 & $\ldots \ldots \ldots$ & 4 & $\left.1.79^{* *}\right)$ & 1.79 \\
\hline 461 & $\ldots \ldots \ldots$ & 7 & 1.644 & 1.647 \\
\hline 480 & $\ldots \ldots \ldots$ & 3 & 1.623 & 1.625 \\
\hline
\end{tabular}

*) checked with a beryl-standard

**) a broad peak.

The lines not indexed are probably due to impurities.

growth of two amphibole components (Eskola and Sahlstein 1930b, Sahama 1956) or to elliptical polarization due to the non-coincidence of the principal optical and absorption directions (Faye and Nickel 1970). As magnesioriebeckite-1 does not show any striations indicating intergrowth, its incomplete extinctions seem to be of the latter type.

A fraction from the separated sample was taken for $x$-ray diffraction studies. The magnesioriebeckite-1 diffraction pattern (Table 3) was indexed by comparison with the patterns of synthetic magnesioriebeckite (Ernst 1960) and of the riebeckite from Hurricane Mt. (Borg and Smith 1969). The unit cell dimensions (Table 2) and the d-values were calculated by regression analysis. The computer calculations were done by the Computing Center of the University of Helsinki. The 020 reflection of magnesioriebeckite- 1 is presumed to be covered by the reflection $\left(d_{\text {meas }}=9.36 \AA\right)$ of talc impurity.

In Table 4 the chemical composition and physical properties of the Puolanka magnesioriebeckite-1 are compared with those of some other magnesioriebeckites and with the theoretical compound. The Puolanka amphibole has a slight excess of $\mathrm{Al}_{2} \mathrm{O}_{3}, \mathrm{MgO}$ and $\mathrm{CaO}$ and a marked deficiency of $\mathrm{Fe}_{2} \mathrm{O}_{3}$ compared with the theoretical compound $\mathrm{Na}_{2} \mathrm{Mg}_{3} \mathrm{Fe}_{2} \mathrm{Si}_{8} \mathrm{O}_{22}$ $(\mathrm{OH})_{2}$. The chemical compositions, the refractive indices and the extinction angles of the magnesioriebeckites from Puolanka and Zesfontein are very similar, but the axial angles and and specific gravities differ. The arfvedsonitic affinities of the Puolanka amphibole are obvious when its chemical composition is compared with that of the Bizan magnesioriebeckite, which belongs to the magnesioriebeckite-ferroglaucophane group (Miyashiro 1957).

The unit cell dimensions of the Puolanka magnesioriebeckite-1 are systematically somewhat smaller than those of the averages of synthetic magnesioriebeckites (Table 4).

The Puolanka magnesioriebeckite-2 occurs only at a depth of $48.40-48.70 \mathrm{~m}$ and was inadequate for chemical analysis. It shows complete extinctions in sections close to (100), but not in others, and is zoned in the same way as magnesioriebeckite- 1 . The semiquantitative electron probe microanalyses of the cores and darker margins of both Puolanka magnesioriebeckites are given in Table 5 . The analyses were done by a Geoscan microanalyser with a chemically analyzed natural hornblende as standard. The analyses are averages of three determinations. Excluding the $\mathrm{Na}_{2} \mathrm{O}$ content, the wet chemical and the microanalysis of the Puolanka magnesioriebeckite-1 are in moderately good agreement. As a whole, magnesioriebeckite- 2 contains more iron and less $\mathrm{MgO}$ than magnesioriebeckite-1, so that it is slightly more riebeckitic in 
TABle 4.

Chemical compositions and physical properties of some magnesioriebeckites.

\begin{tabular}{|c|c|c|c|c|c|}
\hline & 1 & 2 & 3 & \multicolumn{2}{|c|}{4} \\
\hline 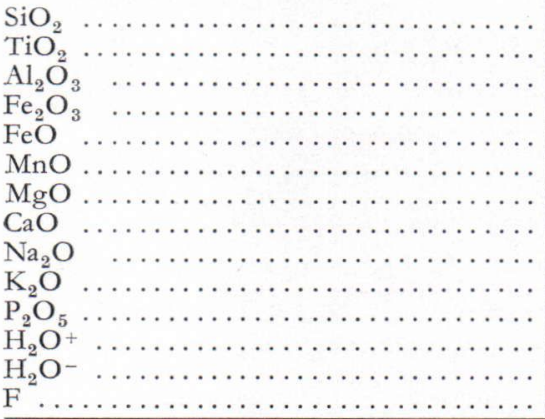 & $\begin{array}{r}57.20 \\
0.15 \\
1.13 \\
14.85 \\
0.57 \\
0.04 \\
15.53 \\
1.11 \\
7.20 \\
0.19 \\
0.06 \\
2.34 \\
0.00 \\
0.01\end{array}$ & $\begin{array}{r}55.62 \\
0.26 \\
4.54 \\
12.99 \\
3.53 \\
1.25 \\
11.98 \\
1.95 \\
5.58 \\
0.36 \\
0.07 \\
1.96 \\
0.00\end{array}$ & $\begin{array}{r}54.4 \\
\\
2.9 \\
14.5 \\
2.3 \\
1.5 \\
15.8 \\
1.5 \\
6.5 \\
\\
0.8\end{array}$ & & \\
\hline & 100.38 & 100.09 & 100.2 & \multicolumn{2}{|c|}{100.00} \\
\hline 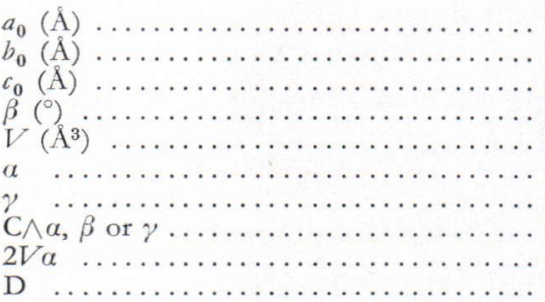 & $\begin{array}{r}9.700 \\
17.944 \\
5.273 \\
103.5 \\
892.4 \\
1.657 \\
1.670 \\
9-13^{\circ} \\
0-4^{\circ} \\
3.116\end{array}$ & $\begin{array}{r}9.65 \\
17.81 \\
5.30 \\
103.3 \\
886.0 \\
1.660 \\
1.670 \\
28^{\circ} \\
43^{\circ}\end{array}$ & $\begin{array}{r}1.659 \\
1.668 \\
9-21^{\circ} \\
49-52^{\circ} \\
3.151\end{array}$ & $\begin{array}{l}9.76 \\
17.97 \\
5.31 \\
103.9 \\
904 \\
1.655 \\
1.672 \\
32^{\circ} \\
0-20^{\circ} \\
3.15\end{array}$ & $\begin{array}{c}9.73 \\
17.95 \\
5.30 \\
103.3 \\
901 \\
\left.1.654^{*}\right) \\
\left.1.672^{*}\right) \\
\left.4-13^{\circ} *\right) \\
-\end{array}$ \\
\hline
\end{tabular}

*) for white light.

1) Puolanka magnesioriebeckite-1 (Table 2).

2) Magnesioriebeckite, quartzose schist, Bizan, Japan (Miyashiro and Iwasaki 1957). Unit cell dimensions are from Ernst (1963, Table 10).

3) Magnesioriebeckite, hematite ore, Zesfontein, South-West Africa (Deer, Howie and Zussman 1963, Table 54, No. 11)

4) Theoretical magnesioriebeckite $\mathrm{Na}_{2} \mathrm{Mg}_{3} \mathrm{Fe}_{2}^{+3} \mathrm{Si}_{8} \mathrm{O}_{22}(\mathrm{OH})_{2}$.

a) end member magnesioriebeckite (Borg 1967).

b) average of seven synthetic magnesioriebeckites (Colville et al. 1966, Table 2-3).

composition. The margins of both minerals are richer in iron and poorer in $\mathrm{MgO}$, in $\mathrm{CaO}$ and, especially in the case of magnesioriebeckite-1, poorer in $\mathrm{Al}_{2} \mathrm{O}_{3}$ than the cores. The $\mathrm{Na}_{2} \mathrm{O}$ content seems to be almost constant.

In white light, using the abbreviations of Borg (1967), magnesioriebecite-1 has $\mathrm{R}$ and magnesioriebeckite-2 $\mathrm{O}$ indicatrix orientation. Both magnesioriebeckites show optic axial dispersion (Fig. 3). The incomplete extinction greatly hampered the U-stage determinations. Contrary to the glaucophanic amphiboles described by Banno (1960) the optic axial dispersion of the Puolanka magnesioriebeckites is $r>v$ for normal-symmetric (O) and $\mathrm{r}<\mathrm{v}$ for parallelsymmetric $(\mathrm{R})$ orientations.

The extinction angle dispersion seems to be almost linear and is stronger for magnesioriebeckite-2. Crossed axial plane dispersion of alkalic amphiboles has previously been described by Jans (1964) and Jans and de Béthune (1968). In accordance with the investigation by Jans (1964) the point of the Puolanka magnesioriebeckite-1 falls in the field in his diagram, where the position of the optic axial plane is variable (Fig. 4). 
TABLE 5

Partial semiquantitative chemical analyses (electron probe microanalyses by Kauko Laajoki) and optical data of the Puolanka magnesioriebeckites

\begin{tabular}{l|r|r|r|r}
\hline & \multicolumn{2}{|c|}{1} & \multicolumn{2}{|c}{2} \\
\cline { 2 - 5 } & \multicolumn{1}{c|}{$\mathrm{a}$} & \multicolumn{1}{c|}{$\mathrm{b}$} & $\mathrm{a}$ & \multicolumn{1}{c}{$\mathrm{b}$} \\
\cline { 2 - 5 } & & & & \\
$\mathrm{SiO}_{2} \ldots \ldots \ldots \ldots$ & 58.8 & 59.5 & 59.1 & 59.2 \\
$\mathrm{Al}_{2} \mathrm{O}_{3} \ldots \ldots \ldots$ & 1.5 & 0.5 & 0.9 & 0.8 \\
$\mathrm{Fe}_{2} \mathrm{O}_{3}{ }^{*} \ldots \ldots \ldots$ & 16.7 & 20.8 & 20.0 & 23.1 \\
$\mathrm{MgO} \ldots \ldots \ldots$ & 16.1 & 14.4 & 14.4 & 12.3 \\
$\mathrm{CaO} \ldots \ldots \ldots$ & 1.4 & 0.5 & 1.4 & 0.2 \\
$\mathrm{Na}{ }_{2} \mathrm{O} \ldots \ldots \ldots$ & 5.8 & 5.9 & 5.4 & 5.8 \\
\hline & 100.3 & 101.6 & 101.2 & 101.4 \\
\hline
\end{tabular}

*) total iron

\begin{tabular}{|c|c|c|}
\hline$a \ldots$ & $\left.1.658 \pm 0.002^{* * *}\right)$ & $1.663 \pm 0.002$ \\
\hline$\gamma \ldots \ldots \ldots \ldots \ldots$ & $1.672 \pm 0.002 * * *)$ & $1.671 \pm 0.002$ \\
\hline $\mathrm{C} \wedge \alpha \ldots$ & $9-13^{\circ}$ & $14-17^{\circ}$ \\
\hline $2 V \alpha \ldots \ldots \ldots \ldots$ & $0^{\circ} \pm 4^{\circ}$ & $65^{\circ} \pm 5^{\circ}$ \\
\hline O.A.P.**) $\ldots \ldots$ & $/ /(010)$ & $\perp(010)$ \\
\hline $\begin{array}{r}\left.\mathrm{b}^{* *}\right) \\
\text { Pleochroism } \\
* *\end{array}$ & $=\beta$ & $=\gamma$ \\
\hline$\alpha \ldots \ldots \ldots \ldots \ldots$ & light blue & greenish blue \\
\hline$\beta \ldots \ldots \ldots \ldots$ & light violet & yellowish \\
\hline$\gamma \ldots \ldots \ldots \ldots$ & yellowish & violet blue \\
\hline
\end{tabular}

**) for white light, other optical data for Na-light.

***) mean from table 2.

1) Magnesioriebeckite-1, drill hole No. 10, depth $44.75 \mathrm{~m}$. a) almost colourless core, b) more coloured margin.

2) Magnesioriebeckite-2, drill hole No. 10, depth $48.60 \mathrm{~m}$. a) blue core, b) more coloured margin.

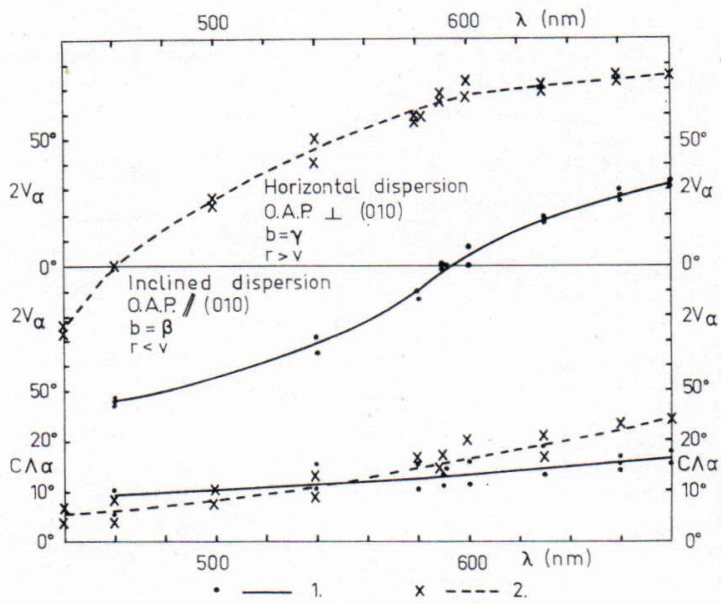

Frg. 3. The optical axial angle dispersion curves, extinction angle dispersion curves and crossed axial plane dispersion of the Puolanka magnesioriebeckite-1 (1) and magnesioriebeckite-2 (2).

\section{Penninite}

Chlorite occurs as anhedral light yellow flakes ranging up to $2 \mathrm{~mm}$ in diameter. When blown on a chlorite rich sample smells like clay. For chemical analysis chlorite was separated from the same sample by the same method as magnesiorie-

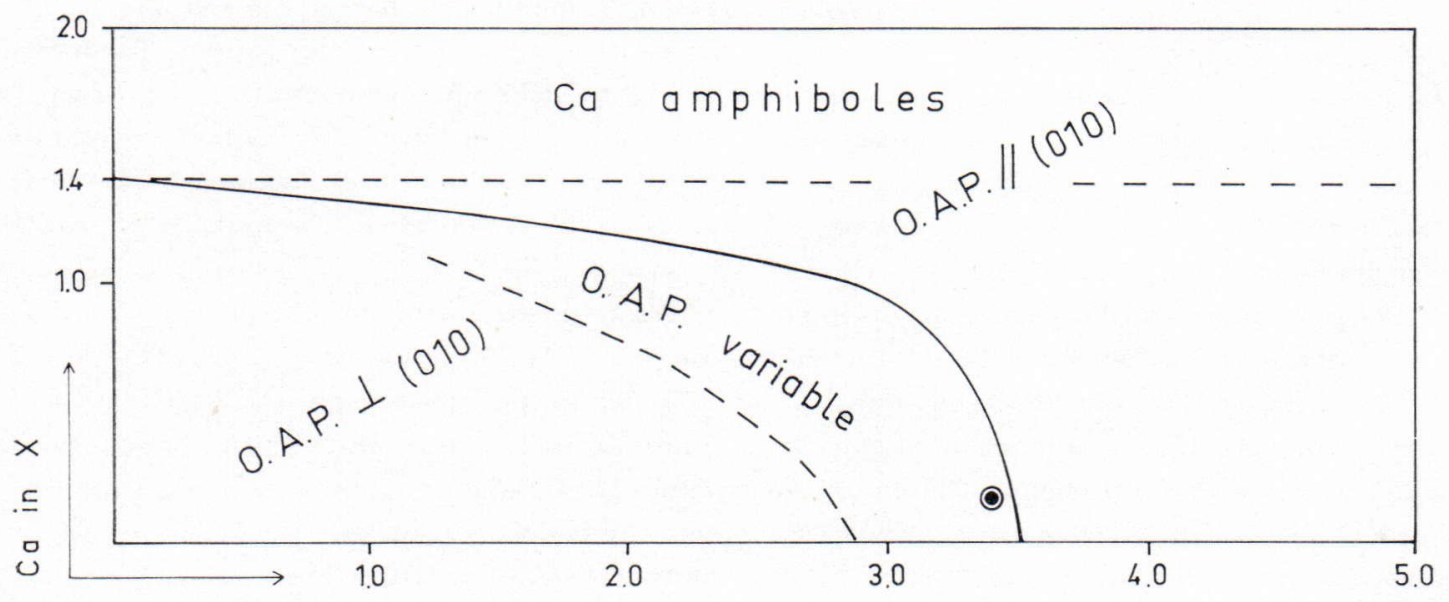

$(M g+A l)$ in $Y$

FIG. 4. Variation of the position of the axial plane of the amphiboles as a function of the contents of Ca in $\mathrm{X}$-positionand $(\mathrm{Mg}+\mathrm{Al})$ in Y-position. Simplified from Jans (1964). The point of the Puolanka magnesioriebeckite-1 is shown by a black dot. 
TABle 6

Chemical composition and physical properties of the penninite from drill hole No. 10, Puolanka, NE Finland. Anal. by Pentti Ojanperä.

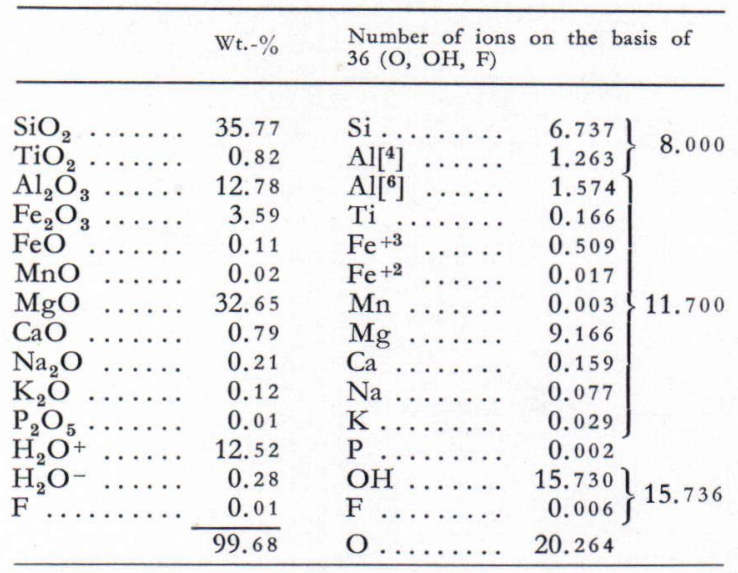

$\left(\mathrm{Mg}_{9.17} \mathrm{Fe}_{02}^{+2} \mathrm{Ca}_{.16} \mathrm{Al}_{1.57} \mathrm{Fe}_{51}^{+3} \mathrm{Ti}_{.17} \mathrm{Na}_{.08} \mathrm{~K}_{03}\right)_{11.71}$ $\left(\begin{array}{lll}\mathrm{Si}_{6.74} & \left.\mathrm{Al}_{1.26}\right)_{8.00} & \mathrm{O}_{20.26} \\ (\mathrm{OH}, \mathrm{F})_{15.74}\end{array}\right.$

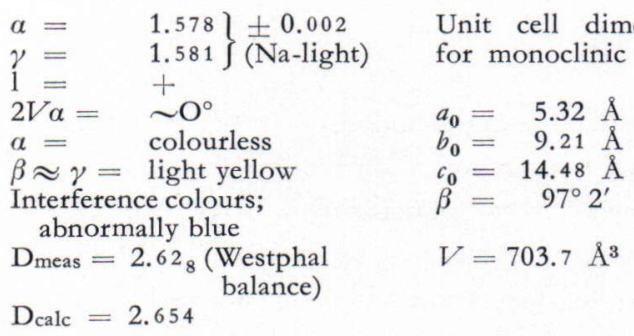

riebeckite. No foreign grains were detected in the final sample. Slight quantities of the same reddish brown pigment were observed as in magnesioriebeckite. The chemical analysis is given in Table 6 . The $\mathrm{CaO}$ content of chlorite may be due to interstitial carbonate. According to the classification of Hey (1954) and of Foster (1962), the Puolanka chlorite is penninite.

There are very few penninites in the recent literature for which both chemical composition and physical properties have been given. One of these is the "penninite» from Raajärvi, Finland (Nuutilainen 1968, p. 60). However, if the classifications of Hey (1954) and of Foster (1962) are strictly adhered, it should be called chamosite or clinochlore, respectively. Compared

\section{TABLE 7}

Indexed powder diffraction pattern of the Puolanka penninite. Filtered copper radiation with quartz standard. $\mathrm{X}$-ray runs by $\mathrm{P}$. Kallio.

\begin{tabular}{|c|c|c|c|c|}
\hline & $b k l$ & $I$ & $d_{\text {meas }}$ & $d_{\text {cale }}$ \\
\hline 001 & $\ldots \ldots \ldots \ldots$ & $\begin{array}{l}9 \\
1\end{array}$ & $\begin{array}{r}14.37 \\
9.41\end{array}$ & 14.37 \\
\hline 002 & $\ldots \ldots \ldots \ldots$ & 10 & 7.20 & 7.19 \\
\hline 003 & $\ldots \ldots \ldots \ldots$ & 10 & 4.79 & 4.79 \\
\hline \multirow[t]{3}{*}{004} & $\ldots \ldots \ldots \ldots$ & 9 & 3.59 & \multirow[t]{3}{*}{3.59} \\
\hline & & 1 & 3.194 & \\
\hline & & $\begin{array}{l}1 \\
4\end{array}$ & $\begin{array}{l}3.120 \\
2.869\end{array}$ & \\
\hline 005 & $\cdots \cdots \cdots \cdots$ & 4 & 2.869 & 2.874 \\
\hline 131, & $202 \ldots \ldots$ & 1 & $\left.2.572^{*}\right)$ & 2.581 \\
\hline 132 , & $201 \ldots \ldots$ & 1 & $\left.2.543^{*}\right)$ & 2.540 \\
\hline 132, & $20 \overline{3} \ldots \ldots$ & 1 & $2.442 *)$ & 2.441 \\
\hline 006 & $\cdots \ldots \ldots \ldots$ & 1 & $\left.2.398^{*}\right)$ & 2.395 \\
\hline 133, & $20 \overline{4} \ldots \ldots$ & 1 & 2.276 & 2.263 \\
\hline 134, & $20 \overline{5} \ldots$ & $1 / 2$ & 2.094 & 2.074 \\
\hline 007 & $\ldots \ldots$ & 1 & 2.048 & 2.053 \\
\hline $13 \overline{5}$ & $204 \ldots$ & 1 & $\left.2.009^{*}\right)$ & 2.012 \\
\hline 060 & $33 \overline{1} \ldots \ldots$ & 1 & $\left.1.535^{*}\right)$ & 1.535 \\
\hline
\end{tabular}

*) a broad peak.

The lines not indexed are probably due to impurities.

with the Puolanka penninite, the Raajärvi "penninite» contains only slightly more $\mathrm{Fe}_{2} \mathrm{O}_{3}$, $\mathrm{FeO}$ and $\mathrm{Al}_{2} \mathrm{O}_{3}$ and slightly less $\mathrm{SiO}_{2}$. The Raajärvi "penninite» has $\alpha=1.578, \gamma=1.580$, $2 \mathrm{~V} \alpha 20^{\circ}$ and positive elongation. Evidently owing to its higher iron content the Raajärvi »penninite» differs from the Puolanka penninite in pleochroism ( $\alpha=$ colourless, $\beta \approx \gamma$ blue green) and in interference colours (abnormally brown) ( $c f$. Table 6$)$.

The indexing of the powder pattern (Table 7) was based on ASTM card No. 10-183. On the basis of the powder pattern the Puolanka penninite is monoclinic (Brown and Bailey 1962, Table 3-4). The unit cell dimensions (Table 6) were calculated from the formulae given by Shirozu (1958, p. 216). These dimensions are almost identical with those given in the ASTM card mentioned above. The basal spacing $\mathrm{d}_{\mathbf{0} 01}$ of chlorite is principally influenced by the substitution of $\mathrm{Al}$ by Si. Quantitative relationships 
TABLE 8.

Trace element contents (ppm) of penninite- and magnesioriebeckite-bearing rock, of carbonate rock and limestones from Puolanka. Anal. by V. Hoffren and R. Danielsson.

\begin{tabular}{|c|c|c|c|c|c|c|c|c|c|}
\hline & 1 & 2 & 3 & 4 & 5 & 6 & 7 & 8 & 9 \\
\hline 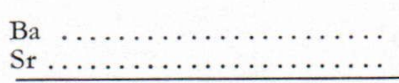 & $\begin{array}{r}800 \\
0 \\
\end{array}$ & $\begin{array}{r}2700 \\
110 \\
\end{array}$ & $\begin{array}{r}0 \\
80 \\
\end{array}$ & $\begin{array}{r}0 \\
400 \\
\end{array}$ & $\begin{array}{r}200 \\
70 \\
\end{array}$ & $\begin{array}{l}100 \\
160\end{array}$ & $\begin{array}{r}0 \\
200 \\
\end{array}$ & $\begin{array}{r}300 \\
50 \\
\end{array}$ & $\begin{array}{r}0 \\
210\end{array}$ \\
\hline & $\mathrm{Zr}$ & $\mathrm{Ti}$ & $\mathrm{Mn}$ & $\mathrm{Cu}$ & $\mathrm{v}$ & $\mathrm{Cr}$ & $\mathrm{Sc}$ & $\mathrm{Y}$ & $\mathrm{Ga}$ \\
\hline $\begin{array}{ll}1 *) & \ldots \\
\left.2^{*}\right) & \ldots\end{array}$ & $\begin{array}{r}50 \\
0\end{array}$ & $\begin{array}{r}1500 \\
210\end{array}$ & $\begin{array}{r}1000 \\
340\end{array}$ & $\begin{array}{l}64 \\
10\end{array}$ & $\begin{array}{r}70 \\
0\end{array}$ & $\begin{array}{r}76 \\
6\end{array}$ & $\begin{array}{r}22 \\
0\end{array}$ & $\begin{array}{r}100 \\
0\end{array}$ & $\begin{array}{r}10 \\
0\end{array}$ \\
\hline
\end{tabular}

*) Nb, Ta, U, Th, Ce were not detected.

1) Penninite- and magnesioriebeckite-bearing rock, Pahkavaara, drill hole No. 10, depth $44.35-44.90 \mathrm{~m}$.

2) Carbonate rock, Pahkavaara, drill hole No. 10, depth $68.90 \mathrm{~m}$.

3) Limestone, Iso Salmijärvi, drill hole No. 15, depth $163.70 \mathrm{~m}$.

4) " " " " ", " $377.10 \mathrm{~m}$.

5) ", ", drill hole No. 16, depth $185.50 \mathrm{~m}$.

6) 》 , Rällinmäki.

7) " , Pieni Salmijärvi.

8) » , Poikkijärvi.

9) " , Iso Kaitanen.

of this substitution have been examined by severa authors (Hey 1954, Brinley and Gilleryl 1956, in Deer, Howie and Zussman 1962, and Shirozu 1958). The curve of Shirozu (1958, p. 219) gives $\left[\mathrm{Al}^{4}\right]$ content 1.38 for the Puolanka penninite. This results is in good agreement with the $\left[\mathrm{Al}^{4}\right]$ content (1.26) obtained from the chemical analysis. The correlation between the total Al content and basal spacing $\mathrm{d}_{001}$ is not so good if the regression equation given by Albee (1962, p. 867), is used. It gives $\left[\mathrm{Al}^{4}+\mathrm{Al}^{6}\right]$ content 2.15 , compared with the value (2.81) calculated from the analysis. The $\mathrm{a}$ and $\mathrm{b}$ cell parameters of chlorite are influenced by the $\mathrm{Fe}$ content. Using regression equations given by Hey (1954) $a_{\mathrm{o}}=5.32 \AA$ and $b_{\mathrm{o}}=9.21 \AA$ were obtained for the Puolanka penninite, which are the same as those measured (Table 6).

\section{Discussion}

Magnesioriebeckite occurs in alkalic igneous rocks and in carbonatites (Kovalenko 1968), in low grade schists, in marbles, as crocidolite in metamorphosed ironstones and as an authigenic mineral (Miyashiro and Banno 1958, Ernst 1964, Deer, Howie and Zussman 1963).

Magnesioriebeckite is consequently stable over a wide range of physical conditions in the rocks of appropriate bulk composition (high soda, magnesia and ferric iron, and low alumina and lime) (Ernst 1960). In his discussion on the genesis of the South Australia magnesioriebeckite, (crocidolite) Ernst (1960) states that it possibly crystallized under conditions of soda metasomatism involving relatively high $\mathrm{P}_{\mathrm{CO}_{2}}$. $\mathrm{He}$ also suggests that the formation of the Bizan magnesioriebeckite doubtless reflects the high $\mathrm{Fe}_{2} \mathrm{O}_{3}$ content of the rock (Ernst 1960).

Chlorite is widely distributed in low grade metamorphic rocks, especially in those of the greenschist facies. In igneous rocks it generally occurs as a hydrothermal alteration product of primary ferromagnesian minerals (Deer, Howie and Zussman 1962).

The site and the association of the penninite-and magnesioriebeckite-bearing rocks of Puolanka indicate that these rocks formed from metadiabases by dislocation metamorphism. The formation of magnesioriebeckite is intimately associated with the replacement of albite by 
carbonate. The trace element contents (Table 8) suggest that the carbonate substance is of sedimentary origin, even thouhg its $\mathrm{Ba}$ content greatly deviates from that of the limestones (mainly dolomites) of the Puolanka area. The Puolanka magnesioriebeckite is supposed to have formed by the reaction:

(1) $2 \mathrm{NaAlSi}_{3} \mathrm{O}_{8}+\mathrm{Fe}_{3} \mathrm{O}_{4}+3 \mathrm{CaMg}\left(\mathrm{CO}_{3}\right)_{2}+$ (albite) (magnetite) (dolomite)

$$
\begin{aligned}
& \mathrm{H}_{2} \mathrm{O}+2 \mathrm{SiO}_{2}=\mathrm{Na}_{2} \mathrm{Mg}_{3} \mathrm{Fe}_{2} \mathrm{Si}_{8} \mathrm{O}_{22}+ \\
& \text { (magnesioriebeckite) } \\
& 3 \mathrm{CaCO}_{3}+\mathrm{FeO}+\mathrm{Al}_{2} \mathrm{O}_{3}+3 \mathrm{CO}_{2} \\
& \text { (calcite) }
\end{aligned}
$$

This equation fulfills both the conditions, high $\mathrm{P}_{\mathrm{CO}_{2}}$ and high $\mathrm{Fe}_{2} \mathrm{O}_{3}$ content, discussed previously. The brownish yellow substance occurring in connection with the carbonates of drill hole No. 10 is thought to represent the excess of substance of this reaction.

The Puolanka penninite is supposed to be a hydrothermal alteration product of biotite from pelitic schists and/or metadiabases due to the following reaction (the approximate formula of biotite is based on the comparison of its $\mathrm{FeO}$ (total $\mathrm{Fe}$ ) and $\mathrm{MgO}$ content with those given by Deer, Howie and Zussman 1962, Table 12, p. 58):

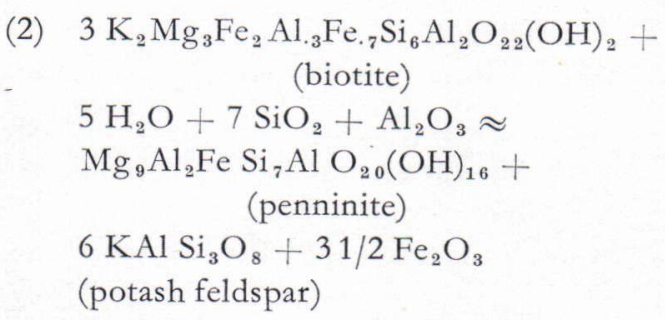

Naturally, the $\mathrm{Fe}_{2} \mathrm{O}_{3}$ released could have taken part in reaction 1 . Since in the shear zone of drill hole No. 10 there is only a small amount of microcline, the potash feldspar formed by reaction 2 must have left the system.

Owing to the inadequate soda (albite) content of the metadiabase and of the other rocks in the shear zones of Iso Salmijärvi the first reaction failed to happen. The second reaction, however, took place and the potash feldspar liberated is seen as microline balls and fragments. The biotite needed must have been of pelitic origin.

Acknowledgements - The authors are indepted to $\mathrm{Mr}$. Arvo Löfgren, Mag.Phil and to Miss Ringa Danielsson, Mag.Phil., for the spectrochemical analyses, to Mr. Väinö Hoffrén, Mag.Phil., for the x-ray fluorescence analysis, to Mr. Pekka Kallio, Mag.Phil., for the x-ray runs, to Mr. Erkki Ristimaa for mineral separations, and to Misses Marjo-Riitta Kujala and Lea Leiponen for drawing the figures. Sincere thanks are due to Dr. Ilmari Haapala and Dr. Atso Vorma for reviewing the manuscript. 


\section{REFERENCES}

Albee, A. L. (1962) Relationships between mineral association, chemical composition and physical properties of the chlorite series. Am. Mineral. 47, 851-870.

ASTM-Powder diffraction data file, sets 1-18. American Society for Testing and Materials.

BANNO, S. (1960) Notes on rock-forming minerals (13). Optic axial dispersion of glaucophanic amphiboles. Journ. geol. Soc. Japan, 66, 357-358.

Bor G, J. Y. (1967) Optical properties and cell parameters in the glaucophane-riebeckite series. Contr. Mineral. and Petrol. 15, 67-92.

Bor G, J. Y. and Smrth, D. K. (1969) Calculated X-ray patterns for silicate minerals. Geol. Soc. Am., Memoir 122.

Brown, B. E. and Bailey, S. W. (1962) Chlorite polytypism, Pt 1, Regular and semi-random one-layerstructures. Am. Mineral. 47, 819-850.

Colville, P. A., Ernst, W. G. and Gilbert, M. C. (1966) Relationships between cell parameters and and chemical compositions of monoclinic amphiboles. Am. Mineral. 51, 1727-1754.

Deer, W. A., Howie, R. A. and Zussman, J. (1962) Rock-Forming Minerals. Vol. 3, Sheet silicates. London.

- , - and - (1963) Rock-Forming Minerals. Vol. 2, Chain silicates. London.

ERnst, W. G. (1960) The stability relations of magnesioriebeckite. Geochm. et Cosmochim. Acta 19, 19-40.

- (1963) Polymorphism in alkali amphiboles. Am. Mineral. $48,241-260$.

- (1964) Petrochemical study of coexisting minerals from low-grade schists, Eastern, Shikoku, Japan. Geochim. et Cosmochim. Acta 28, 1631-1668.

Eskola, P. and Sahlstein, Th, G. (1930 a) On astrophyllite-bearing nepheline syenite gneiss. Found as a boulder in Kiihtelysvaara, Eastern Finland. Compt. rend. Soc. géol. Finlande 3, 77-88.

Eskola, P. und Safilstein, Th. G. (1930 b) Über die unvollkommene Auslöschung einiger Amphibole. Compt. rend. Soc. géol. Finlande 3, 89-95.

FAye, G. H. and Nickel, E. H. (1970) The effect of chargetransfer processes on the colour and pleochroism of amphiboles. Canad. Mineral. 10, 616-635.

Foster, M. D. (1962) Interpretation of the composition and a classification the chlorites. U. S. Geol. Survey, Prof. Paper 414-A.
Hey, M. H. (1954) A new review of the chlorites. Mineral. Mag. 30, 277-292.

Hytönen, K. and Heik kinen, A. (1966) Alkali amphibole of Otanmäki, Finland. Compt. rend. Soc. géol. Finlande 38, $145-156$.

JANs, H. (1964) De plaats van borgnizite in de groep van alkali-amfibolen volgens zijn chemische samenstelling en fysische eigenschappen. Thesis. Katholike Universitete Leuven.

— and de BÉthune, P. (1968) The alkalic amphibole of the Lueshe carbonatite. Int. Mineral. Association; Papers and proceedings of the fifth general meeting, Cambridge, England. August 30-September 3, 1966, pp. 312-314. Min. Soc. London.

Kovalenko, V. J. (1968) On the chemical composition, properties, and mineral paragenesis of riebeckite and arfvedsonite. Int. Mineral. Association; Papers and proceedings of the fifth general meeting, Cambridge, England August 30-September 3, 1966, pp. 261-284. Min.Soc. London.

LAajoki, K. (1973) On the geology of the South Puolanka area, Finland. Geol. Surv. of Finland Bull. 263.

Mryashiro, A. (1957) The chemistry, optics, and genesis of the alkali-amphiboles. Jour. Fac. Sci. Univ. Tokyo, Sect. II, vol. II, part 1, 57-83.

- and Iwasakr, M. (1957) Magnesioriebeckite in crystalline schists of Bizan in Sikoku, Japan, Journ. Geol. Soc. Japan, 63, 698-703.

- and BANNo, S. (1958) Nature of glaucophanitic metamorphism. Am. Journ. Sci. 256, 97-110.

Nuutilainen, J. (1968) On the geology of the Misi iron ore province, Northern Finland. Ann. Acad. Sci. Fennicae, Ser. A, 96.

PaArma, H. (1970) A new find of carbonatite in North Finland, the Sokli plug in Savukoski. Lithos 3, 129133.

Puustinen, K. (1972) Richterite and actinolite from the Siilinjärvi carbonatite complex, Finland. Bull. géol. Soc. Finland 44, 83-86.

Sahama, Th. G. (1956) Optical anomalies in arfvedsonite from Greenland. Am. Mineral. 41, 509-512.

Shirozu, H. (1958) X-ray powder patterns and cell dimensions of some chlorites in Japan, with a note on their interference colours. Mineral. Journ., Japan 2, $209-223$.

Manuscript received, January 26, 1973. 